\title{
Defansif Tıp ve Defansif Tıp Konusunda Yapılan Akademik Çalışmalar Üzerine Bir Derleme
}

\author{
Fatma MANSUR*
}

\author{
Ömer CEYLAN**
}

Geliş Tarihi (Received): 11.09.2021 - Kabul Tarihi (Accepted): 02.11.2021

\section{$\ddot{\mathbf{O} z}$}

Tıp yazınında çok uzun süredir yer alan fakat son yıllarda önemi artmış olan defansif tıp; hekimlerin hastanın teşhis ve tedavisi için gerekli olan tahlil ve tetkiklerin ötesine geçmesi veya malpraktis davasına konu olabilecek tıbbi işlemlerden kaçınması durumudur. Hekimler cezai müeyyide doğuracak davalardan kaçınmak, yaptıkları veya yapmadıkları işlemlerden dolayı tazminatla karşılaşmamak, mesleki sorumluluk sigorta poliçe primlerini arttırmamak, hastayı memnun etmek veya hasta tarafindan herhangi bir şiddete maruz kalmamak gibi amaçlarla defansif tıbba başvurmaktadırlar. Defansif tıp bir taraftan hastaların daha ayrıntılı ve derinlemesine değerlendirmesini sağlarken diğer taraftan sağlık bakım maliyetlerinde artışa sebebiyet verdiği gibi hastaların gereksiz tahlil ve tetkiklerle zarar görme riskini de içermektedir. Defansif tıp hakkında Türkiye'de yapılan çalışmalar son yıllarda artış göstermesine rağmen yeterli sayıda çalışma olmadığı görülmektedir. Bu çalışmada, öncelikle defansif tıp uygulamaları kavramsal olarak ortaya konulmaya çalışılmış, defansif tıbbın sebepleri, sonuçları ve maliyeti irdelenmiştir. Çalışmanın devamında sağlık alanında görülen defansif tıp uygulamaları ve bu uygulamaların sonuçları üzerine son 5 yılda yapılmış olan ulusal ve uluslararası çalışmaların incelenmesi yapılmıştır. Çalışmanın amacı mevcut çalışmalar kapsamında defansif tıp kavramını bütün yönleriyle ortaya koyup gelecekte yapılacak çalışmalara 1şık tutmaktır.

Anahtar Kelimeler: Defansif tıp, pozitif defansif tıp, negatif defansif tıp, hukuki sorumluluk

\section{A Review Of Academic Studies On Defensive Medicine and Defensıve Medicine}

\begin{abstract}
Defensive medicine, which has been in the medical literature for a very long time, has increased in importance in recent years and defined as the situation where physicians go beyond the tests and examinations necessary for the diagnosis and treatment of the patient or avoid medical procedures that may be the subject of malpractice lawsuits. To avoid lawsuits that may result in criminal sanctions, and not to face compensation for the actions they have done or not done, and not to increase professional liability insurance policy premiums, physicians utilize defensive medicine to please the patient or not be exposed to any violence. While defensive medicine provides a more detailed and in-depth evaluation of patients, it has caused an increase in healthcare costs and including the risk of patients being harmed by unnecessary tests and examinations. Despite the fact that the number of studies on defensive medicine in Turkey has increased significantly over the years, it has been observed that not enough studies have been carried out. In this study, firstly, defensive medicine practices were evaluated conceptually, and then the causes, consequences and cost of defensive medicine were examined. Later, the national and international studies on defensive medicine practices in the field of health and the results of these practices in the last 5 years were examined. The aim of this study is to reveal the concept of defensive medicine in all its aspects within the scope of current studies and to shed light on future studies.
\end{abstract}

Keywords: Defensive medicine, positive defensive medicine, negative defensive medicine, legal responsibility.

* Dr. Öğr. Üyesi, Ankara Hacı Bayram Veli Üniversitesi, İktisadi ve İdari Bilimler Fakültesi, Sağlık

Yönetimi Bölümü, fatma.mansur@hbv.edu.tr

**Doktora Öğrencisi, Ankara Hacı Bayram Veli Üniversitesi, Lisansüstü Eğitim Enstitüsü, Săglık

Yönetimi Bölümü, omer.ceylan@hbv.edu.tr 


\section{Giriş}

Tibbi uygulamalar sirasinda hastada bedenen veya ruhen zarara sebep olan veya hastanın hayatına mal olan eylemler tıbbi hata olarak nitelendirilmektedir. Her ne kadar sağlık hizmetinde temel amaç kişiyi bedenen ve ruhen iyi hale getirmek olsa da hizmetin doğası gereği kişinin sağlı durumunun iyiye gitmesinin yanında kötüleşmesi ihtimalide her zaman mevcuttur. Bu kötüleşme bazen hekimin bilgisizliği, tecrübesizliği veya ihmalinden kaynaklı malpraktis şeklinde ortaya çıkabileceği gibi bazen de gerekli bütün tıbbi uygulamalar yapılmasına rağmen komplikasyon şeklinde ortaya çıkabilmektedir.

Son dönemde sağlık hukukunda yaşanan gelişmeler ile birlikte malpraktis davalarına olan ilginin artması, medyada tıbbi hatalara ilişkin haberlerin çoğalması, kişilerin sağlık ile ilgili farkındalığının artması, tıp teknolojisinde ve hasta haklarında yaşanan gelişmeler ile birlikte sağlıkla ilgili beklentinin yükselmesi gibi sebeplerden ötürü sağlık alanında şikâyetlerde büyük bir artış söz konusudur. Özellikle tanı ve tedaviye ilişkin şikâyetlerin büyük çoğunluğu tıbbi hatalara ilişkin olmakta ve hekimlere yöneltilmektedir. Bu tarz şikayetlerde bir ön değerlendirme mekanizması bulunmadığından malpraktis ve komplikasyon ayırımına gidilmeden tıbbi hatalara ilişkin bütün şikayetler hukuksal inceleme ile sonuçlanabilmektedir. Yapılan bir çalışmada malpraktis konulu şikâyetlerin \% 83'ünde tedaviyi uygulayan hekimin ihmal veya kusuruna ilişkin herhangi bir kanıt bulunmadığı ortaya konulmuştur (Virapongse vd., 2008, s. 2363). Artan davalar hekimlerin tıbbi işlemlerde kendilerini korumaya yönelik bir yaklaşım sergilemelerine ve bu yaklaşımın artış göstermesine sebep olmuştur. Defansif tıp uygulamaları Amerika Birleşik Devletleri, Japonya, İngiltere, Avustralya, Avrupa ve Türkiye'de çok yaygın görülmektedir (Assing Hvidt vd., 2017, s. 2; Başer, Kolcu, Çığırgil, Kadınkız ve Öngel, 2014, s. 17)

Literatüre bakıldığında defansif tıp tanımında bir uzlaşma olduğu görülmektedir. Buna göre sağlık profesyonellerinin hukuksal sıkıntı yaşamamak adına gereksiz tedavi uygulaması, gerekmediği halde tahlil-tetkik istemesi veya riskli vakalardan kaçınması defansif tıp olarak yorumlanmaktadır. Burada doktor gerekmediği halde tahlil, tektik, konsültasyon isteyip pozitif defansif tıp uygulayabileceği gibi riskli gördüğü hastayı başka yere sevk etmek, riskli girişimsel işlemlerden çekinmek gibi negatif defansif tıp uygulayabilmektedir.

Defansif tıp uygulamaları hekimlerin, başta malpraktis kaynaklı davalardan korunma olmak üzere, hasta ve hasta yakınları ile olası çatışmadan kaçınma ve zorunlu mesleki sigorta primlerinin artmasını engelleme gibi amaçlarla yaptıkları bir takım uygulamalardır. $\mathrm{Bu}$ 
uygulamaların sebebi hasta menfaatinden ziyade hekimin kendini korumasına yöneliktir (Başer vd., 2014, s. 17).

Defansif tıp uygulamaları bir taraftan hastaların gereksiz tıbbi tahlil ve tetkikler ile riske atılmasına sebebiyet verirken diğer taraftan bireysel ve kamusal olarak mali yük oluşturmaktadır. Yapılan bir çalışmada defansif tıp uygulamalarının sadece Amerika Birleşik Devletleri'nde yıllık en az 60 milyar dolar ekstra sağlık harcamasına sebep olduğu belirtilmiştir (Yan vd., 2017, s. 2342). Her ne kadar defansif tıp hekimlerin yapmış olduğu uygulama olarak görülüp konunun etik boyutları hakkında bazı değerlendirmeler yapılmış olsa da defansif tıp uygulamalarının bireysellikten ziyade bir sistem sorunu olduğu görüşü daha hakimdir (Bester, 2020, s. 413).

Bu çalışmada, öncelikle defansif tıp uygulamaları kavramsal olarak ortaya konulmaya çalışılmış, defansif tıbbın sebepleri, sonuçları ve maliyeti irdelenmiştir. Çalışmanın devamında sağlık alanında görülen defansif tıp uygulamaları ve bu uygulamaların sonuçları üzerine son 5 yılda yapılmış olan ulusal ve uluslararası çalışmaların incelenmesi yapılmıştır. Çalışmanın amacı mevcut çalışmalar kapsamında defansif tıp kavramını bütün yönleriyle ortaya koyup gelecekte yapılacak çalışmalara 1şık tutmaktır.

Araştırmada Mayıs-Haziran 2021 tarihleri arasında Google Akademik, Ankara Hacı Bayram Veli Üniversitesi Kütüphane Kaynakları ve YÖK Tez Arşivi’nde 2016 yılından itibaren yayımlanmış çalışmalar taranmıştır. Taramalarda anahtar kelime olarak "defansif tıp", "savunmacı tıp", “çekinik tıp", “defansif uygulama" ve "defensive medicine” kelimeleri kullanılmış olup, erişim izni olmayan çalışmalar kapsam dışı bırakılmıştır.

\section{Defansif Tip}

Günümüzde yaygın olarak kullanılan defansif tıp, literatürde savunmacı tıp, çekinik tıp olarak da adlandırılmaktadır. Defansif tıp kavramı ABD'de hekimlere yönelik şikayet ve davaların arttığı 1970'li yıllarda ortaya çıkmıştır. En sade haliyle defansif tıp, "hekimlerin sorumluluktan kaçınmak ve dava edilme korkusu ile standart tıbbi uygulamalardan sapmaları" olarak tanımlanmaktadır (Baungaard vd., 2020, s. 1). Literatürde yapılan bütün tanımlardan yola çıkarak geniş anlamda, "hekimlerin malpraktis davalarından ve hasta/ hasta yakınlarından gelebilecek olası şikayetlerden kaçınma veya tanı için önemli olabilecek bulguları gözden kaçırma korkusuyla fazladan tahlil ve tetkik istemesi, gerekmediği halde bir kısım tıbbi prosedürler uygulaması, fazladan konsültasyon talebinde bulunması, tedavisi tamamlanmış olmasına rağmen hastayı fazladan yatırması, riskli gördüğü veya riskli tıbbi müdahale 
gerektiren hastaları sevk etmesi gibi tutum ve davranışlar ile genel kabul görmüş tıbbi ilkelerden sapmaları” şeklinde tanımlanabilir (Ünal, 2020, s. 9)

Kavramsal olarak defansif tıp uzun süredir literatürde yer almasına rağmen özellikle son dönemde hasta haklarında yaşanan gelişmeler, dijitalleşme ile birlikte hastaların kişisel sağlık kayıtlarına ulaşmalarının kolaylaşması, hastalıklara yönelik tanı ve tedaviler konusundaki bilgilere kolay erişim ve medyanın etkisi ile hekimlerin tanı ve tedaviye ilişkin davranışları ciddi bir şekilde takip edilmeye ve sorgulanmaya başlamıştır. Bunun sonucu olarak hekimlere yönelik malpraktis iddiaları ve hekimlerin yaptıkları veya yapmadıkları tıbbi işlemlere yönelik adli ve idari soruşturmalarda ciddi artış yaşanmıştır. Bu soruşturmalar hekimleri bir taraftan moral ve motivasyon açısından yıpratırken diğer taraftan da ceza ve ciddi tazminatlar ile karşı karşıya bırakmıştır. Bu sürecin doğal sonucu olarak hekimler ceza davalarında kendilerini garantiye almak için tedavi sürecinde genel kabul görmüş standart prosedürlerin dışına çıkmaya, bir başka deyişle hekimler tıbbi gereklilikten ziyade kendilerini koruma güdüsüyle hareket etmeye başlamışlardır.

Hekimler arasında defansif tıp uygulamalarının yaygınlaşmasının başlıca sebepleri şu şekilde sıralanabilir; (Kara, 2020, s. 6; Toraman ve Çarıkçı, 2019, s. 46)

1. Şikâyet ve dava edilme korkusu,

2. Artan malpraktis davaları,

3. Medyanın etkisi,

4. Sağlık hizmeti sunanlara karşı şiddet,

5. Hata yapma kaygısı,

6. Hasta beklentilerinin artmas1,

7. İletişim zayıflı̆̆

8. Performans sistemi,

9. Artan mesleki sigorta primleri.

Defansif tıbbın temel tanımına bakıldığında hastaya hiç fayda sağlamayan ya da çok az fayda sağlayan tıbbi uygulamalar olduğu görülmektedir. Ancak hekim tarafından gerçekleştirilen tıbbi uygulamalardan hangilerinin defansif tıp uygulamaları olduğunun tespiti, hasta-hekim ilişkisinde mevcut olan asimetrik bilgi ve hekimler arası tıbbi yorum farkından dolayı çoğu zaman mümkün olmamaktadır.

Burada üzerinde durulması gereken önemli bir husus nelerin defansif tıp içerisinde sayılmayacağıdır. Hekimlerin bir malpraktise veya hukuksal incelemeye karşı kendilerine koruma sağlamak için atacağı bütün adımlar defansif tıp olarak değerlendirilemez. Örneğin, muhtemel şikayetler veya davalara karşı tıbbi kayıtların özenli tutulması veya hastalara ait 
ayrıntılı notlar tutulması defansif olarak değerlendirilemeyecek uygulamalar arasındadır. Bunun yanında hekimin tanı konusunda bir tereddüttü varsa ve bunu gidermek amaciyla daha ayrıntılı tahlil ve tetkikler istiyorsa bu davranışda defansif tıp uygulamaları içinde değerlendirilemez. Burada temel ayrım tıbbi uygulamanın amacıdır ve şayet bir tıbbi uygulama hastanın tedavi başarısını amaçlıyorsa defansif tıp kapsamına girmezken hekimi korumayı amaçlıyorsa defansif tıp kapsamına girmektedir (Bester, 2020, s. 3).

\subsection{Defansif Tıp Türleri}

Defansif tıp ile ilgili tanımlar incelendiğinde defansif tıp uygulamalarının iki başlık altında incelendiği görülmektedir. Bunlarda ilki pozitif defansif tıp olarak adlandırılan ve temelinde malpraktis davalarından kaçınmak ya da hukuksal sıkıntı yaşamamak adına tıbbi açıdan gerekli veya herhangi bir faydası olmayan tıbbi işlemler gerçekleştirmesidir. Kavramsal olarak pozitif kelimesinin kullanılması bu tür defansif tıbbın olumlu olduğu manasına gelmemekte, hekimin kendini koruma güdüsüyle olması gerekenden fazla tıbbi işlem yapmasını ifade etmektedir. Bundan ötürü bu tür uygulamalar "güvence davranış1" şeklinde de adlandırılmaktadır. Diğer tür olan negatif defansif tıp ise hekimlerin hukuksal sıkıntı yaşamamak adına riskli gördüğü hasta ve tıbbi işlemlerden kaçınmasıdır. Negatif defansif tıpta hekim, mecbur kalmadıkça yüksek riskli hastalara müdahale etmekten kaçınmakta, başka bir kuruma veya hekime sevk etmeye çalışmaktadır. Burada geçen negatif kelimesi sunulması gereken tıbbi hizmetlerin o hekim tarafından sunulmamasını ifade etmektedir. Bundan ötürü bu tür uygulamalar "kaçınma davranışı" olarak da anılmaktadır (Aydaş, 2014, s. 67; U.S. Congress, 1994, s. 13).

\subsubsection{Pozitif defansif tip uygulamaları.}

Pozitif defansif tıp, hekimin hastasından gelebilecek herhangi bir şikayet veya malpraktis iddiasına karşı onu ikna etmek veya olası bir dava sürecinde savunmasını güçlendirmek için tanı ve tedaviye yönelik bütün işlemleri gerçekleştirdiğini kanıtlamak adına tıbbi açıdan bir değeri olmayan, tanı ve tedaviye herhangi bir katkı sağlamayan fazladan tıbbi işlemler yapmasıdır (Studdert vd., 2005, s. 2609). Pozitif defansif tıp uygulamaları hekimlerin tıbbi kusur ve ihmal iddialarına karşı kendilerini güvenceye almak adına tıbbi hizmetleri olması gerekenden fazla kullanmasıdır (Montanera, 2016, s. 355).

Pozitif defansif tıp uygulamalarının, hastalara ilişkin kayıtların detaylı ve düzenli tutulması, hasta ile daha yakından ilgilenilmesi, hasta ile iletişimi güçlendirmesi, burada başvurulan tetkikler sayesinde normalde gözden kaçması muhtemel bulguların tespiti açısından 
olumlu yönleri bulunmaktadır, bu bakımdan pozitif defansif tıbba ilişkin uygulamaların hasta ve hekimler açısından faydalı olduğu yönünde görüşler mevcuttur (Bergen, 1974, s. 1188; Localio vd., 1993, s. 366; Y1lmaz, Polat ve Begüm, 2014, s. 16). Pratikte pozitif defansif tıp uygulamaları çoğu zaman hastalar üzerinde iyi bir izlenim bırakmakta ve hekimin hastaları ile daha iyi ilgilendiği şeklinde yorumlanmaktadır ancak bu tarz davranışlar kapsamında yapılan tomografi gibi gereksiz radyolojik tetkikler, endoskopi, biyopsi gibi girişimsel işlemler ve cerrahi müdahaleler hastaya uzun vadede zarar verebileceği gibi hastayı bedenen ve ruhen de olumsuz etkileyebilir. Bunun dişında bu tarz uygulamalar hem bireysel hem de kamusal açıdan büyük bir mali yük oluşturmaktadır (Localio vd., 1993, s. 367; Summerton, 1995, s. 27; Y1lmaz vd., 2014, s. 23).

Pozitif defansif tıp uygulamalarının bazı durumlarda hastada mevcut olan fakat belirti göstermeyen rahatsızlıkların erken tanı ve tedavisine olanak sağladığı öne sürülse de, bu uygulamalarda temel amacın hasta sağlığı olmadığı hekimin olası şikayetlere karşı kendine hukuki güvence sağlamak maksadı ile hareket ettiği yani hasta faydasından ziyade kendi bireysel faydasını ön planda tuttuğu, bunun da meslek ahlakı ve tıbbi etik açısından doğru bir davranış olmadığı belirtilmektedir (Summerton, 1995, s. 27; Yılmaz vd., 2014, s. 23).

Literatürde yapılmış çalışmalara bakıldı̆̆ında hekimlerin en fazla başvurdukları pozitif defansif tıp uygulamaları (Ünal, 2020, s. 17):

- Tıbbi açıdan gereğinden daha fazla tahlil ve tetkik isteme,

- Tıbbi açıdan gereğinden daha fazla radyolojik görüntüleme isteme,

- T1bbi gereklilik olmadığı halde hastayı gözlemde tutma,

- Hastaya gereksiz veya fazla yatış verme,

- Tanı ve tedavi bakımından ihtiyaç olmamasına rağmen fazladan konsültasyon isteme,

- Fazla ayrıntılı kayit tutma,

- Tıbbi prosedürler ve sağlık durumu hakkında hastalara çok detaylı açıklamalar yapma,

- Tibbi açıdan gerekmediği halde invaziv işlem önerme.

\subsubsection{Negatif defansif tıp uygulamaları.}

Negatif defansif tıp, yasal olarak risk oluşturabilecek davranışlardan kaçınma çabasını yansıtmaktadır (Studdert vd., 2005, s. 2609). Defansif tıp davranışlarının temelinde olan hekimin tıbbi hata yapma ve şikâyet edilme kaygısı burada da kendini göstermektedir. Ancak pozitif defansif tıpta hekim standart prosedürlerin ötesine geçip fazladan tıbbi işlem yaparken negatif defansif tıpta hekim yapması gerekeni yapmamakta ve tıbbi müdahaleden kaçınmaktadır (Catino, 2011, s. 1; Studdert vd., 2005, ss. 2609-2610; Y1lmaz vd., 2014, s. 24). 
Negatif defansif tıp uygulamamalarında, hekimin tıbbi bilgi ve becerisi hastanın teşhis ve tedavisi için yeterli olmasına rağmen hekim, hasta veya yakınlarından kendisini şikayet etme ihtimali yüksek olan hastaları tedavi etmekten, tıbbi tedavi açısından yüksek riskli gördüğü hasta ve tıbbi işlemleri yapmaktan kaçınarak sorumluluktan kurtulmaya çalışmaktadır (Catino, 2011, ss. 1-2; Studdert vd., 2005, ss. 2609-2610).

Hekimin almış olduğu eğitim ve öğrenimine göre yapabileceği veya yapması gereken asgari tıbbi işlemler belli olduğu için negatif defansif tıp uygulamalarının tespiti pozitif defansif tıp uygulamalarına göre daha kolay olmaktadır. Bununla birlikte bir hekimin yapabileceği tıbbi işlemler hekimin tıbbi bilgi ve becerisinin yanında çalıştığı kurumun kendisine sağladığ imkanlar ile de yakından ilişkilidir. Günümüzde sağlık kuruluşları sahip oldukları tıbbi imkanlara ve verebildikleri hizmetlere göre ayrılmışlardır, bu bakımdan kişiler hangi sağlık tesisinde hangi hizmeti alabileceklerini az çok bilmektedirler. Örneğin Türkiye'de sağlık kuruluşları birinci, ikinci ve üçüncü basamak sağlık kuruluşları olarak ayrıma tabi tutulmuş, hangi basamakta hangi hizmeti veren kuruluşun yer aldığı belirtilmiştir. Bununla birlikte ikinci ve üçüncü basamak sağlık kuruluşları da kendi içinde ayrıma tabi tutulmuştur, yine Sağlık Bakanlığı'na bağlı sağlık tesisleri kendi içinde A-I, A-II, B, C, D, E gibi gruplara ayrılmış ve hangi grupta hangi hizmetin verileceği/verilmesi gerektiği net olarak belirtilmiştir. Bundan dolayı, negatif defansif tıp uygulamaları daha açık bir şekilde görülebilmektedir. Örneğin, B grubu bir hastanede çalışan genel cerrahın olağandışı bir durum yokken apandisit ameliyatı olması gereken kişiyi üçüncü basamak hastaneye yönlendirmesi gibi.

Negatif defansif tıp uygulamalarının mali külfeti pozitif defansif tıp uygulamalarına göre düşük olmasına rağmen hasta sağlığı açısından daha büyük risk oluşturmakta ayrıca hasta memnuniyetine de olumsuz yansımaktadır (Tancredi ve Barondess, 1978, s. 879). Özellikle sağlık hizmet sunumunun sınırlı olduğu küçük yerleşim yerlerinde kişilerin çok fazla alternatifleri olmadığı için hekim tarafından uygulanacak negatif defansif tıp orada yaşayanların sağlık hizmetine erişimini engelleyecektir (Studdert vd., 2005, s. 2609).

Pratikte en çok karşılaşılan negatif defansif tıp uygulaması olan hasta sevkine bakıldığında, şayet sevk işlemi sağlık tesisinin imkanlarının yetersiz olması veya daha teşekkülü bir hastanede müdahale edilmesinin hasta sağlığı açısından iyi olacağı kaygısıyla yapılıyorsa bu davranış olumludur ve defansif tıp olarak değerlendirilemez. Ancak o sağlık tesisinde yeterli imkan varken sırf şikayet edilme kaygısıyla hasta sevk ediliyorsa bu davranış olumsuz defansif tıp olmasının yanında tıbbi etik açısından da uygun değildir. Bununla birlikte sevk sırasında ortaya çıkabilecek bir komplikasyon veya sevkten kaynaklı tıbbi müdahalede gecikme hekimi daha büyük sıkıntılar ile karşı karşıya bırakabilmektedir (Morrison, 1994, ss. 
127-128). Başka bir ifade ile hekimin kendini koruma amacıyla hastaya gerekli tanı ve tedaviyi uygulamadan kaçınıp hastayı başka bir hastane veya hekime sevk etmesi şeklinde göstereceği negatif defansif tıp hekimin çok daha ciddi malpraktis davası ile karşı karşıya kalmasına sebebiyet verebilmektedir (Tancredi ve Barondess, 1978, s. 879).

Negatif defansif tıp konusunda yapılan çalışmalarda bu uygulamaların en çok kadın doğum, acil tıp, beyin cerrahisi, ortopedi ve travmatoloji gibi malpraktis şikayetlerinin çok fazla yaşandığı uzmanlık dallarında görüldüğü, hatta bazı sağlık kuruluşlarında kafa travmalı hastaların alınmaması, çocuk hastalara yönelik tıbbi müdahalelerden kaçınılması gibi negatif defansif tıp uygulamalarının sistematikleştiği ve bu branşlarda hasta mağduriyetleri yaşandığ belirtilmektedir (Yahata, 2011, s. 175)

Son dönemlerde hekimler arasında özellikle negatif defansif tıp uygulamaları artış göstermiş, hekimler riskli olmasına rağmen daha önce yaptıkları ameliyat ve bir takım girişimsel işlemleri yapmaktan çekinmeye ve bu hastaları üçüncü basamak hastanelere sevk etmeye başlamış, bunun sonucu olarak bazı hastanelerde cerrahi branş servisleri sadece rutin ufak ameliyatların yapıldığı servislere dönüşmüşlerdir (Yeşiltaş, 2018, s. 45). Bunun başlıca sebepleri artan şikayet ve malpraktis davaları, hekimlere yönelik şiddetin yarattı̆ğ olumsuz hava, artan mesleki sigorta primleri ve medyanın olumsuz etkisi olarak gösterilebilir. Yahata (2011) tarafından yapılan bir çalışmada Japonya'da 2004 yılında hamile bir kadının sezaryen operasyonunda öldüğ̈̈, bu olayın ve sonrasındaki malpraktis sürecinin medyada çok fazla gündem olduğu, bir çok kişi tarafından bu olayın ve olayın yaşandığı tarihin Japonya'da defansif tıp uygulamalarının başlangıcı olarak kabul edildiği belirtilmiştir (Yahata, 2011, ss. 179-181).

Literatürde yapılmış çalışmalara bakıldığında hekimlerin en fazla başvurdukları negatif defansif tıp uygulamaları (Ünal, 2020, s. 19):

- Komplikasyon ihtimali yüksek olan hastalardan kaçınma,

- Komplikasyon riski oluşturan tıbbi işlemlerden kaçınma,

- Şikayet etme riski yüksek hastalardan kaçınma,

- Tıbbi açıdan kompleks görünen ve birden çok şikâyeti bulunan hastalardan kaçınma,

- Yüksek riskli tıbbi müdahalelerden kaçınma,

- Tedavi için hastayı kabul etmeme,

- Hastayı başka bir sağlık kuruluşuna veya hekime sevk etme. 


\section{Defansif Tıp Uygulamalarının Maliyeti}

Defansif tıp uygulamalarının kişisel stres, doktorlar için zaman ve itibar kaybı gibi dolaylı maliyetlerinin yanında, ülke ekonomisini doğrudan etkileyen parasal maliyeti de bulunmaktadır (Osti ve Steyrer, 2017, s. 400). Ancak ne yazık ki defansif tıbbın parasal maliyetini tam olarak belirlemek mümkün değildir (Reschovsky ve Saiontz-Martinez, 2018, s. 1501).

Defansif tıp konusunda en kapsamlı çalışmaların yapıldığı Amerika Birleşik Devletleri'nde defansif tıbbın maliyetinin 1987'de 12 milyar dolar olduğu ve giderek arttığı, bu süreçte yapılan maliyet tasarrufları ve agresif uygulamalar ile 5 yıllık bir sürede 41 milyar dolar civarı tasarruf sağlandığı buna rağmen 2000 yılı öncesinde tüm sağlık harcamaları içinde defansif tıp uygulamalarının \%5 ile \%9 arasında maliyeti olduğu belirtilmektedir. Amerika Birleşik Devletlerinde sadece ortopedistlerin yaptığı defansif tıp uygulamalarının maliyetinin yıllık en az 2 milyar dolar olduğu belirtilmektedir (Osti ve Steyrer, 2017, s. 399). Yapılan güncel çalışmalarda defansif tıbbın toplam sağlık maliyetleri içinde \%8 ila \%20 arasında yer tuttuğu belirtilmektedir (Reschovsky ve Saiontz-Martinez, 2018, s. 1498).

Avrupa ve Türkiye'de ise defansif tıp uygulamalarının fiili maliyeti hakkında çok az çalışma mevcuttur. Avusturya'da yapılan bir çalışmada defansif tıp uygulamaları için yapılan harcamaların genel halk sağlığı harcamaları içinde 2012 ve 2013 yıllarında \% 1,62 ile \%3,19 civarında olduğu belirtilmiştir (Osti ve Steyrer, 2017, s. 400). Türkiye'de defansif tıbbın mali boyutu ile ilgili doğrudan çalışmaya rastlanılamamış olmakla birlikte Özer ve Aslan (2020) tarafından defansif uygulamalar kapsamında 596 hasta dosyası üzerinde yapılan doküman incelemesi önemli bilgiler vermektedir. Çalışmaya göre laboratuvar istemlerinde defansif tıp uygulama oranının \%10,6, görüntülemede ise \%14,20 olduğu belirtilmiştir. Defansif tıp davranışlarının yaygınlığı ve çalışma verileri beraber değerlendirildiğinde Türkiye' de sağlık harcamaları içinde defansif tıp uygulamalarının ciddi bir maliyete sebebiyet verdiği açıktır.

\section{Defansif Tıp Uygulamalarının Yaygınlığı}

Hekimler arasında defansif tıp davranışları tüm dünyada ve Türkiye'de yaygın olarak uygulanmaktadır. Çalışmanın bu kısmında son 5 yıl içinde dünyada ve Türkiye'de bu konuda yapılan çalışmaların bulguları 1şığında defansif tıp uygulamaları irdelenmiştir.

Kalkan vd. (2020) tarafından, 140 beyin ve sinir cerrahisi uzmanın katılımı ile gerçekleştirilen çalışmada, çalışmaya katılan 60 (\%42,9) uzmana malpraktis nedeniyle soruşturma/dava açıldığı, uzmanların yüksek riskli uygulamalardan kaçınmasında \% 87,8 'lik bir oran ile komplikasyon ve malpraktis ayrımının net yapılmamasının temel sebep teşkil ettiği, 
ikinci sırada ise hasta ve yakınlarının sözlü hakaret ve şiddet saldırılarından korunma olduğu belirtilmiştir. Çalışmada katılımcıların başvurdukları defansif tıp uygularında kayıtları daha detaylı tutmanın yaygınlığı \% 75, dava etme olasılığı yüksek olan hastalardan kaçınmanın oranı ise $\% 60$ olarak bildirilmiştir.

Toraman ve Çarıkçı (2019) tarafından, 23 öğretim üyesi doktor ile görüşülerek yapılan nitel çalışmada, defansif tıp uygulamalarında başta gelen sebebin tıbbı malpraktis davalarından kaçınmak olduğu görülmüştür. Katılımcıların büyük çoğunluğu tıbbi malpraktis davalarının, iş yaşamlarında üzerlerinde ciddi baskıya neden olduğunu, tanı ve tedavi sürecindeki işlemleri defalarca gözden geçirdiklerini belirtmişlerdir. Dava edilme korkusunun yanında şikayet mercilerine yapılan ve çoğu zaman asılsız çıkan başvuruların hekimlerin iş yükünü çok arttırdığı bunun da hekimleri olumsuz etkilediği belirtilmiştir. Çalışma sonucunda ulaşılan önemli bir başka bulgu ise günden güne yeterli tıbbi eğitim almamış hekimlerin sayısının arttığ bu hekimlerin hastalara daha defansif yaklaştığıdır. Ayrıca sağlık alanında görülen şiddet ve performans sisteminin de defansif tıp uygulamalarını tetiklediği belirtilmiştir.

Saruhan vd. (2018) tarafından, diş hekimleri arasında defansif tıp uygulamalarının yaygınlığının belirlenmesi amacıyla 120 diş hekiminin katılımı ile gerçekleştirilen çalışmada, diş hekimleri arasında malpraktis davalarından korunmak için defansif tıp uygulamalarının sıklıkla kullanıldığı sonucuna varılmıştır. Hekimler tarafından komplikasyon-malpraktis ayrımının tam olarak yapılmaması, medyanın hekimlere karşı olumsuz tutum içinde olması ve sağlık sisteminin hekimleri şiddete karşı koruyamaması defansif davranışlarda bulunmaya neden olan etkenler olarak görülmüştür. Çalışmada diş hekimleri arasında en sık başvurulan defansif tıp davranışlarının, daha ayrıntılı belge hazırlamak, yüksek risk içeren ve invaziv (cerrahi işlem ve tedavi gerektiren uygulamalar) prosedürlerde çekinik davranmak, gerekmediği halde fazla tetkik -konsültasyon istemek ve hastayı sevk etmek olduğu belirtilmiştir.

Özata vd. (2019) tarafından, diş hekimlerinin defansif tıp uygulamalarına yönelik tutum, bilgi ve davranışlarının belirlenmesi amacıyla, Konya ilinde kamu ve özel sektörde çalışan 229 diş hekiminin katılımıyla yapılan çalışmada, katılımcıların büyük kısmının kavramsal olarak defansif tıbbın içeriğini tam olarak bilmedikleri ancak kendilerini malpraktis davalarına karşı korumak için işlem öncesi aydınlatılmış onam formlarına daha fazla özen gösterdikleri, yapacakları uygulamalar hakkında hastaya daha detaylı bilgi verdikleri, kayıtları daha özenli tuttukları, fazladan görüntüleme ve konsültasyon istedikleri, fazladan ilaç reçete ettikleri, komplikasyon riski olan, kompleks tedavi gerektiren ve riskli hastaları sevk ettikleri belirtilmiştir. 
Mutlu ve Mutlu (2019) tarafından, hasta hakları birimine yapılan şikayetlerin aile hekimlerinin defansif tıp uygulamalarına etkisini belirlemek üzere yaptıkları çalışmaya İstanbul Kadıköy'de görev yapan 209 aile hekimi katılmıştır. Çalışmaya katılan hekimler arasında defansif tıp eğiliminin yıllar itibariyle arttı̆̆ı, mesleğe yeni başlayan hekimlerde ve günlük hasta sayısı fazla olan hekimlere yönelik yapılan şikayetlerin daha fazla olduğu buna paralel olarak bu hekim gruplarında defansif tıp uygulamalarının daha sık görüldüğü belirtilmiştir.

Göcen vd. (2018) tarafından, hekimlerin, defansif tıp uygulamaları hakkındaki bilgi ve tutumları, işe bağlı gerginlik ve tükenmişlik düzeylerini belirlemek amacıyla, Dicle Üniversitesi Tıp Fakültesi Hastanesi'nde çalışan 200 hekimin katılımıyla gerçekleştirilen çalışmada, cerrahi branşlarda çalışan hekimlerin dahili branşlarda çalışan hekimlere göre dava edilme oranlarının 4,6 kat daha fazla olduğu bu bakımdan cerrahi branşlarda defansif tıp uygulamalarının daha yaygın olduğu, uzmanlık eğitiminin 3-5 yılında olan hekimlerin ilk 2 yılı içerisinde olan hekimlere göre daha az defansif tıp uygulamalarına başvurdukları, hakkında daha önce malpraktis davası açılmış olan hekimlerin defansif tıp uygulamalarına daha sık başvurdukları belirtilmiştir. Defansif tıp uygulamalarının başlıca sebepleri olarak, malpraktis davalarının giderek artması, bu davaların medyada fazlaca yer alması ve hekimlerin yeterli derecede tıp hukuku eğitimi almaması sayılmıştır.

Kumtepe vd. (2020) tarafından, defansif tıp ile ilgili acil tıp asistanlarının tutumlarının değerlendirilmesi amacıyla 153 hekimin katılımıyla gerçekleştirilen çalışmada, katılımcıların tamamının defansif uygulamalar sergiledikleri ve tıbbi hata yapmaktan çekindikleri belirtilmiştir. Katılımcıların \%96,7'sinin malpraktis davası ile karşılaşma risklerinin yüksek olduğu; \%83,7'sinin malpraktis iddialarından korunmak için dava etme olasılığg yüksek kompleks tıbbi problemleri olan hastalardan kaçındıkları; sadece \%4,6'sının endikasyon dışı hasta yatırmadığı; tüm katılımcıların malpraktisten korunmak adına, fazladan konsültasyon isteme, fazladan laboratuvar ve radyolojik tetkik isteme gibi defansif uygulamalara başvurdukları; \%11,8'inin de fazladan ilaç yazdığı belirtilmiştir. Hekimlerin \%98,7'si malpraktis iddialarından kaçınmak adına tıbbi uygulamaları hastalara daha detaylı açıkladığını, \%99,3'ü aydınlatılmış onam formlarına daha fazla önem verdiğini ve hekimlerin tamamı kayıtları daha detaylı tuttuğunu belirtmiştir. Ayrıca hekimlerin \%70’i zorunlu mali sorumluluk sigortasının tıbbi uygulamalarda rahatlık sağlamadığını da ifade etmiştir.

Yorulmaz ve Sabırlı (2019) tarafından, sağlık hizmetlerinde defansif tıp ve hekimlerin karar verme algıları arasındaki ilişkiyi incelemek amacıyla Konya ilinde özel hastanelerde çalışan 102 hekimin katılımıyla gerçekleştirilen çalışmada, hekimlerin defansif tıp konusunda kavramsal olarak yeterli bilgiye sahip olmadıkları ancak çalışmaya katılan hekimlerin büyük 
kısmının hukuki bir sıkıntı ile karşılaşmamak için tıbbi uygulamalar hakkında hastalara daha detaylı bilgi verdikleri, tıbbi kayıtlara ve aydınlatılmış onam formlarına daha fazla özen gösterdikleri belirtilmiştir. Yine malpraktis davalarının medyada fazlaca yer almasının hekimleri tedirgin ettiği vurgulanmıştır.

Altındiş vd. (2019) tarafından, hekimlerin sağlık uygulamalarındaki defansif yaklaşımlara bakış açılarının ve buna ilişskin pratiğe yansıyan unsurların değerlendirilmesi amacıyla Sakarya Üniversitesi Sakarya Eğitim Araştırma Hastanesi’nde görev yapan 68 hekim ile yüz yüze görüşerek yapılan tanımlayıcı tipteki çalışmada, hekimlerin \%80,9'u her hastayı potansiyel davacı olarak görme tedirginliğinde, \%78,1'i tıbbi açıdan yüksek risk içeren müdahaleler kabul etmeme eğiliminde ve \%95,5'i medyanın hekimlere karşı olumsuz tutum içinde olduğunu belirtmiş ve \%60,3’ü sağlık sisteminin hekimleri tam olarak korumadığını ifade etmiştir. Çalışmadaki diğer önemli hususlar ise yeni Türk Ceza Kanunu’nun hekimlik ile ilgili maddelerinin hekimlerde tedirginlik uyandırdığı, yeni Türk Ceza Kanunu'ndan sonra defansif tıp uygulamalarının arttığı, ayrıca malpraktis ve komplikasyon ayrımının netleştirilmesi gerektiğidir.

Yeşiltaş ve Erdem (2018) tarafından, şiddet ve defansif tıp uygulamalarının sebepleri, sonuçları ve bu konularda alınabilecek önlemlerin neler olabileceğini belirlemeye yönelik yapılan çalışmada, defansif tıp uygulamalarının başlıca sebeplerinin şiddet görme, malpraktis, şikayet edilme korkusu, hasta önyargısı, medyanın olumsuz etkisi, hekim-hasta iletişimsizliği, hasta yoğunluğu, mesleki deneyim yetersizliği, sağlık sistemi ve maddi kayıplar olduğu; defansif tıp uygulamalarının başlıca sonuçlarının ise ekonomik kayıp, uzmanlık seçimlerinde değişim, hastaların başarılı hekim bulamaması, tedavide gecikme, başarılı hekime ücret ile ulaşabilme, iş yükünde artış, hekimlerin erkenden emekliye ayrılmak istemeleri olduğu belirtilmiştir.

Ünal (2020) tarafından defansif tıp uygulamalarının, öncülleri ve sonuçlarına ilişkin hekim algılarının belirlenmesi amacıyla 1724 hekimin katılımıyla yapılan çalışmada, defansif tıbbın başta gelen sebeplerinin, dava ve şikayet edilme korkusu, yönetim tarafından hekimlere yeterli destek verilmemesi, medya ve şiddete maruz kalma kaygısı olduğu belirtilmiş. Hekimler arasında en yaygın pozitif defansif tıp uygulamalarının fazladan tahlil, tektik, görüntüleme ve konsültasyon istemi olduğu; en yaygın negatif defansif tıp uygulamalarının ise hastayı sevk etmek olduğu vurgulanmıştır. Yine katılımcılar tarafından defansif tıp uygulamalarının başlıca sonuçları hasta sağlığı açısından risk oluşturması ve sağlık harcamalarında artışa sebep olması olduğu belirtilmiştir. Çalışma bulgularına göre hekimlerin pozitif defansif tıp uygulamalarından ziyade negatif defansif tıp uygulamalarına başvurduğu sonucuna varılmıştır. 
Kara (2020) tarafından Edirne'de birinci basamak sağlık kuruluşlarında çalışan hekimlerin defansif tıp uygulamaları hakkında bilgi, tutumları ve bunun klinik pratiklerine etkisini belirlemek amacıyla aile sağlığı merkezlerinde görev yapan 116 hekimin katılımıyla gerçekleştirilen çalışmada, aile hekimlerinin malpraktis davalarıyla karşılaşma riski düşük olmasına rağmen defansif tıp uygulamalarının \%94,8 gibi yüksek bir oranda olduğu, bunun aile hekimlerinin hastaların ilk başvuru noktası olmasından kaynaklandığı; aile hekimlerine karşı açılan dava sayısı çok düşük olmasına rağmen hekimlerin bu konuda ki endişelerinin çok yüksek olduğu ancak katılımcıların defansif tıp kavramının içeriği hakkında tam bilgi sahibi olmadıkları belirtilmiştir. Çalışmada aile hekimlerinin en sık başvurdukları defansif tıp uygulamaların daha detaylı kayıt tutmak ve tıbbi konularda hastalara daha detaylı açıklama yapmak olduğu; defansif tıp uygulamalarının en önemli sebebi medyanın olumsuz etkisi olarak görülürken ardından, şiddet görme kaygısı, meslektaşlarına açılan malpraktis davaları gösterilmiştir. Çalışma sonucunda aile hekimlerince uygulanan defansif tıp uygulamalarının genel olarak hastalara zarar vermeyen hatta olumlu olarak yorumlanabilecek uygulamalar olduğu belirtilmiştir. Son olarak zorunlu sevk zinciri uygulaması olmaması ve aile hekimleri tarafından sevk edilen hastalara ilişkin kayıt tutma alışkanlığı olmadığından dolayı negatif defansif tıp uygulamalarının başında gelen hasta sevk etme ile ilgili sağlıklı veri elde edilemediği de belirtilmiştir.

Banaz (2020) tarafindan hekimlerin defansif tıp ve tıbbi hata tutumlarının incelenmesi amacıyla Konya Selçuk Üniversitesi Tıp Fakültesi Hastanesinde görev yapan 207 hekim ile gerçekleştirilen çalışmada, hekimlerin defansif tıp uygulamalarına karşı tutumlarının ortalamanın üzerinde olduğu, mesleki tecrübe arttıkça defansif davranışlara başvurma oranının azaldığı bu bakımdan en çok defansif tıp uygulamalarına asistan hekimlerin başvurduğu, erkek hekimlerin kadın hekimlerden daha sık negatif defansif tıp uygulamalarına başvurduğu belirtilmiş, hekimlerin defansif tıp kavramını bilmelerine rağmen içeriğine tam olarak hakim olmadıkları ayrıca katılımcıların neredeyse tamamının malpraktis davası ile karşılaşmadıkları vurgulanmıştır.

Pirol'un (2018) hekimlerin karar verme algılarının defansif tıp tutumları üzerine etkisini belirlemek amacıyla Selçuk Üniversitesi Tıp Fakültesi Hastanesinde 165 hekimin katılımıyla yürütülen çalışmada, hekimler arasında defansif tıp eğiliminin yüksek olduğu; negatif defansif tıp uygulamalarına daha çok başvurdukları; hukuki sorun yaşamamak için defansif tıp uygulamalarından tıbbi kayıtları daha detaylı tutma, hastaya daha detaylı açıklama yapma, aydınlatılmış onam formlarına dikkat etme ve endikasyon dahilinde fazla ilaç yazımını yaygın 
olarak kullandıkları ve malpraktis davalarının medyada fazlaca yer almasının tedirginliğe yol açtı̆̆

Kara (2020) tarafından sağlık alanında yaşanan şiddet ve defansif tıp uygulamalarının incelendiği çalışmada, hekimlerin sıklıkla başvurdukları pozitif defansif tıp uygulamalarının gereksiz tetkik ve tahlil istenmesi ve hasta kayıtlarının daha detaylı tutulması; negatif defansif tıp uygulamalarının ise risk içeren tedavilerden ve agresif hastalardan kaçınma olduğu belirtilmiştir. Çalışmaya katılan 30 hekimin \%83,3’ünün fiziksel veya sözlü şiddete maruz kaldığı bu bakımdan defansif tıp uygulamalarının en temel sebebinin de şiddet görme kaygısı olduğu, bunun yanında malpraktis korkusu ve performans sisteminin de bu uygulamalarda çok etkili olduğu belirtilmiştir.

Biçen (2018) tarafindan, tıpta uzmanlık öğrencilerinin defansif tıp konusundaki tutumlarının incelenmesi amacıyla Dokuz Eylül Üniversitesi Tıp Fakültesi'nde 243 katılımcının bulunduğu çalışmada, katılımcıların hukuksal bir sıkıntı yaşamamak adına başvurdukları defansif uygulamaların başında görüntüleme yöntemlerini daha fazla kullanmanın geldiği ve katılımcıların yarısının bu yola başvurduğu, ardından daha fazla konsültasyon isteme ve girişimsel tedavi protokolleri yerine girişimsel olmayan tedavi protokolleri uygulamanın geldiği belirtilmiş, zorunlu mesleki sigortanın hekimlerin işlerini yaparken daha rahat hissetmelerini sağladığı ve son olarak hekimlerin defansif tıp kavramının içeriği hakkında yeterli bilgi sahibi olmadığı vurgulanmıştır.

Özer ve Aslan (2020) tarafından nicel ve nitel araştırma teknikleri kullanılarak hekimlerin defansif tıp konusunda görüşlerinin belirlenmesi amacıyla yapılan çalışmada, katılımcılar arasında defansif tıp uygulamalarına başvurma oranının çok yüksek olduğu, bunun başlıca sebepleri poliklinikler önünde yaşanan yığılmanın yarattığı huzursuzluk ve çok fazla hasta bakma mecburiyetinde kalınması gösterilirken; performans sistemi, dava ve şikayet edilme kaygısı ve şiddetin defansif uygulamalarda etkili olduğu belirtilmiştir. Çalışma kapsamında örneklemi oluşturan hasta dosyaları üzerinde yapılan incelemede laboratuvar istemlerinde hekim tutum puanının \%40,3, uygulama oranının \%10,6; görüntülemede ise hekim tutum puanının \%37,9, uygulama oranının \%14,2 olduğu tespit edilmiştir. Hekimlerin defansif tutumları yüksek olmasına rağmen uygulamanın çok yüksek olmadığı ancak defansif uygulamaların standart uygulama olarak algılanmaya başlandığı da belirtilmiştir.

Tebano vd. (2018) tarafından, enfeksiyon hastalıkları ve klinik mikrobiyoloji uzmanları arasında defansif tıp korkusunu araştırmak amacıyla, 74 ülkeden 830 hekimin katılımıyla yapılan çalışmada, katılımcılar arasında mesleki uygulamaları yüzünden ceza alanların oranının sadece \%0,4 olmasına rağmen katılımcılar arasında mesleklerini icra ederken defansif 
uygulamalara yer verdiğini belirtenlerin oranının \%85 olduğunu; kadınların, 35 yaşından küçük olanların ve malpraktis davalarını takip edenlerin daha defansif davrandıkları; en sık başvurulan defansif davranışların ise, antibiyotik tedavi sürelerinin uzatılması, gereksiz antibiyotik reçete edilmesi, geniş ve yaygın etkili antibiyotikler veya ilaç kombinasyonlarının reçetelenmesi olduğu belirtilmiştir. Son olarak tedavi sürecinde hekime destek olacak prosedürlerin belirlenmesi ve mesleki deneyim paylaşımı için ekip uyumunun yaygınlaştırılması önerilmiştir.

Rudey vd. (2021) tarafindan Brezilya'da defansif tıp uygulamaları ve sezaryen konusunda 403 kadın doğum uzmanı yapılan çalışmada, katılımcıların çoğunun, sezaryeni bir defansif tıp şekli olarak uyguladıkları, vajinal doğum sırasında komplikasyon riski sezaryene göre yüksek olduğundan hekimlerin kendilerini korumak adına sezaryene yöneldiği, bunda hekimlerin yargı sisteminin "komplikasyon" ve "malpraktis" ayrımını net bir şekilde ortaya koyacak profesyonellikte ve yapıda olmadığına inanmalarının etkili olduğu vurgulanmıştır. Çalışmada katılımcıların \%80,6'sına dava açıldığı veya dava açılan bir kadın doğum uzmanını tanıdıklarını doğal olarak defansif tıp uygulamalarının en büyük sebebinin de dava ve şikayet edilme korkusu olduğu, ayrıca hasta ve yakınları tarafından aşağılanma ve medyanın olumsuz etkisinin de defansif tıp uygulanmasında etkili olduğu belirtilmiştir.

Raposo (2019) tarafından yapılan çalışma, hukuk sisteminin, özellikle bakım miktarına ve yapılan işlemlere bakarak hekim hakkında hüküm verdiğini, bu yüzden çok fazla şey yapan doktorların pek ceza almadığını yine hastalarını daha fazla muayene eden ve birkaç farklı tedavi uygulayan hekimleri övdüklerini, çok işlem yapan hekim iyidir algısı oluştuğunu, bu hususun pozitif defansif tıp uygulamalarını yaygınlaştırdığını, aslında defansif uygulama olan prosedürlerin standart prosedür haline gelmeye başladığını, hekimlerin defansif davranma baskısı altına girdiğini ortaya koymuştur. Bunun da ek konsültasyon, ek tahlil - tetkik sayısını artıracağını, standart tedavi uygulamaları yerine çoklu tedavi uygulamalarını yaygınlaştıracağını ve bu uygulamaların toplum için uzun vadede ciddi tehlikelere sebep olacağını belirtilmiştir.

Assing vd. (2017) tarafından, Danimarkalı pratisyen hekimlerin defansif tıp olgusunu anladıkları ve deneyimledikleri şekilde tanımlamak amacıyla odak grup görüşmeleri ile yürütülen çalışmada, katılımcıların defansif tıp uygulamalarını, profesyonelliğe ters düşen, dış talepler nedeniyle gerçekleştirilen, gereksiz ve anlamsız tıbbi eylemler olarak niteledikleri fakat sağlık sitemi, hastaların talep-beklentilerini karşılama kaygısı ve meslektaşlar arasında hatasız görünme isteğiyle bu uygulamalara başvurduklarını belirtmişlerdir.

Zhu vd. (2018) tarafından Çin'deki kadın doğum ve jinekoloji doktorlarının defansif tıbba yönelik tutumlarını belirlemek amacıyla 1486 katılımcı ile yapılan çalışmada, hekimler 
arasında defansif tıp uygulamalarının yaygınlık oranının \%62,9 olduğu ancak hekimlerin büyük çoğunluğunun defansif tıbbı doğru bulmadığı belirtilmiştir. Kadın hekimlerden 1. ve 2. basamakta çalışanların daha defansif davrandıkları ifade edilmiştir. Hastaları rahatlatmak için yapılan fazla tahlil ve tetkiklerin hastanın tedavisine pek katkı sağlamayacağı ancak yan etkilerinin çok fazla olabileceği vurgulanmış, son olarak Çin'de kadın hastalıkları ve doğum alanında defansif tıp uygulamalarının en büyük etkisinin artan sezaryen oranları olduğu, katılımcıların çok küçük bir kısmının endikasyon dışı sezaryen yapmayacağını belirttiği görülmüştür.

Zarei vd. (2019) tarafından İranlı cerrahlar arasında defansif tıp uygulamaları üzerine 235 cerrahın katılımı ile yapılan çalışmada, cerrahların \%06,3'ünün son yıllarda şikayetlerin arttığına inandığı, \%58,1'inin defansif tıp kavramına aşina olduğu ve \%57,7'sinin malpraktis dava öyküsü olduğu, cerrahların \%74,4'ünün her hastanın tıbbi davalar için bir tehdit olabileceğine inandığı belirtilmiştir. En yaygın pozitif defansif tıp davranışlarının, gereksiz biyopsi $(\% 78,7)$, görüntüleme $(\% 72,3)$ ve laboratuvar tetkikleri $(\% 70,6)$ olduğu; en yaygın negatif defansif tıp davranışının yüksek riskli hastaları kabul etmeme $(\% 61,7)$ olduğu vurgulanmıştır. Araştırma bulguları, cerrahların \%67,5'inin defansif tıp davranışlarının hasta güvenliği açısından riskli olabileceğine inandığını, yine cerrahların çoğunun, defansif tıp uygulamalarının kişilerin sağlık hizmetlerine daha az ulaşmasına, sağlık hizmetlerinin maliyetlerinin artmasına ve hekim-hasta ilişkisinin zayıflamasına neden olduğunu düşündüğünü ortaya koymuştur.

Lyu vd. (2017) tarafından Amerika Birleşik Devletlerinde aşırı tedavinin yaygınlığı, nedenleri ve sonuçlarını ortaya koymak amacıyla 2.106 hekimin katılımıyla yapılan çalışmada hekimlerin, reçeteli ilaçların \%22,0'si, testlerin \%24,9'u ve diğer tıbbi prosedürlerin \%11,1'i olmak üzere genel tıbbi bakım işlemlerinin \%20,6'sının gereksiz olduğunu bildirdikleri, bunların en büyük nedenlerinin ise, yanlış uygulama korkusu (\%84,7), hasta baskısı/isteği (\%59) ve tıbbi kayıtlara erişimde güçlük $(\% 38,2)$ olduğu belirtilmiştir.

Ali vd. (2016) tarafından Sudanlı kadın doğum ve jinekoloji uzmanları arasında defansif tıp davranışları konusunda yapılan çalışmada, hekimlerin \%42,7'sinin defansif tıp kavramını bildiğgi, \%71,8'inin defansif tıp uygulamalarına başvurduğu, hekimlerin pozitif defansif tıp uygulamalarına daha çok başvurduğu, en çok başvurulan uygulamaların gerekmediği halde tedavi planı düzenlenmesi (ilaç reçete edilmesi), yüksek riskli tıbbi girişimlerde kaçınmak ve gereksiz tahlil, tetkik yapmak olduğu belirtilmiştir. Dava ve şikayetlerden kaçınmak için katılımcılardan \%6'sının gereksiz ilaçlar reçete ettiği, \%5,1'inin yüksek riskli hastaları tedavi etmeyi reddettiği, \%5,1'inin de endikasyon harici sezaryen yaptığı belirtilmiştir. 
Sun vd. tarafından (2019) yapılan çalışmada, sağlık çalışanlarının kendilerini olası şiddet, malpraktis davaları ve şikayetlere karşı korumak için pasif riskten kaçınma stratejileri uyguladığı; bu uygulamaların aşırı reçete, aşırı muayene ve tetkik gibi defansif tıp uygulamalarını kapsadığı; bu stratejinin tıbbi maliyetleri arttırdı̆̆ı; hizmetin kullanılabilirliğini azalttığı ve bu şekilde tüm toplumu etkilediği belirtilmiştir.

Hossein ve Mina (2018) tarafından defansif tıp uygulamalarını ve nedenlerini belirlemek amacıyla Tahran Üniversitesi Tıp Bilimleri Hastanesinde 240 katılımcı ile yapılan çalışmada, katılımcıların neredeyse yarısının pozitif ve negatif defansif tıp uyguladıkları, mesleki tecrübe arttıkça defansif uygulamaların azaldığının gözlemlendiği, defansif tıbbın hastaların sağlık hizmetine erişimini etkilediği, hekimlerin hastalar ile sık sık sorun yaşama riskinin yüksek olduğu bölgeleri terk ettikleri ve defansif tıp davranışlarının hasta bakımının kalitesini etkilediği ifade edilmiştir.

\section{Sonuç ve Öneriler}

Yapılan literatür araştırması sonucunda en genel haliyle defansif tıp, hekimlerin cezai müeyyide doğuracak davalardan kaçınmak, yaptıkları veya yapmadıkları işlemlerden dolayı tazminatla karşılaşmamak, mesleki sorumluluk sigorta poliçe primlerini artırmamak, hastayı memnun etmek veya hasta tarafından herhangi bir şiddete maruz kalmamak gibi amaçlarla, hastanın teşhis ve tedavisi için gerekli olan tahlil ve tetkiklerin ötesine geçmesi veya malpraktis davasına konu olabilecek tıbbi işlemlerden kaçınması durumu olarak tanımlanabilir. Yapılan çalışmalar dünya genelinde defansif tıp uygulamalarının arttığını, özellikle acil servislerde ve cerrahi branşlarda pozitif defansif tıp uygulamalarının giderek yaygınlaştığını ortaya koymaktadır. Yapılan araştırmalara göre en sık başvurulan pozitif defansif tıp uygulamaları, gereksiz görüntüleme, laboratuvar tetkik istemi, çok ayrıntılı kayıt tutma, endikasyonsuz tedavi ve çoklu ilaç tedavisidir. Negatif defansif tıp uygulamalarında ise sorumluluktan kaçıp hastayı sevk etmek ön plana çıkmaktadır.

Defansif tıp uygulamaları hekim boyutuyla, çekinikliği arttırdığ i için mesleki gelişimi olumsuz etkilemekte ayrıca gereksiz iş ve işlemler ile vakit kaybına sebebiyet vermektedir. Hasta boyutunda, gereksiz iş ve işlemelerin hasta sağlığını uzun vadede olumsuz etkileme riski bulunmakta, sağlığa erişim hakkını kısıtlamakta, bununla birlikte hekime ve sağlık sistemine güveni azaltmaktadır. Ulusal boyutta ise maliyetleri ve harcamaları doğrudan arttırdığı için sağlık ekonomisini olumsuz etkilemenin yanında sağlık insan gücü planlamasını bozmaktadır.

Defansif tıp uygulamalarının başlıca sebepleri, malpraktis davası/şikâyet edilme korkusu, sözlü ve fiziksel şiddete maruz kalmak istememek, hasta beklentilerini karşılama 
kaygısı, medyada yer alan sağlık haberleri, performans sistemi, mesleki yetersizlik ve tecrübe/bilgi eksikliği, hekimin hasta ve/veya yakınları ile zayıf iletişimidir.

Hekimler bir malpraktis davası ile karşılaştıklarında yıllarca adli sürece maruz kalabilmektedir yine hasta tarafından yapılan en ufak şikayette hastane yönetimleri tarafından hekimlerden bilgi/savunma istenmektedir bu uygulamalar ister istemez hekimleri huzursuz etmekte ve zaman kaybı yaratmaktadır. Diğer taraftan yapılan çalışmalar hekimlere karşı yürütülen adli süreçte malpraktis/komplikasyon ayrımının tam yapılmadığını göstermektedir. Gerçekten de ülkemizde sağlık hukuku alanında branşlaşmış mahkemeler olmadığı için bu tarz şikâyetler genel adli yargı tarafından ele alınmakta ve çoğu zaman tıbbi bakımın niteliği değil de miktarı göz önüne bulundurulmaktadır. $\mathrm{Bu}$ bakımdan sağlık alanında ihtisaslaşmış mahkemelerin kurulması daha sağlıklı kararlar verilmesine ve sisteme güvenin tesis edilmesine katkı sağlayacaktır. Diğer taraftan her türlü şikâyette hekimlerden bilgi/savunma alma uygulaması terkedilip, sağlık kurumlarında şikâyetlerin değerlendirilmesi için bir kurul oluşturulmalı, gelen şikâyetlerin burada bir ön değerlendirmeye tabi tutulup, haksız şikâyetler sağlık çalışanına aksettirilmeden cevaplanmalıdır.

Günümüzde sağlık çalışanlarının en büyük kaygılarından biri hasta ve yakınlarından şiddet görmektir. Bu konuda yapılan yasal düzenlemeler maalesef yeterli gelmemekte ve caydırıcı olmamaktadır. Diğer taraftan normalde defansif tıp uygulamaları olan tıbbi işlemler yavaş yavaş standart uygulama olarak görülmeye başlamakta, çok fazla tahlil tetkik yapan hekim iyi hekim olarak algılanmaktadır. Bunun yansıması olarak gereksiz gördüğü için fazla tahlil tetkik yapmayan hekimler çoğu zaman hasta beklentisini karşılamadığı için hasta ile karşı karşıya gelmekte ve fiziksel ya da sözlü şiddete maruz kalabilmektedir. Bunun önüne geçilebilmesi için sağlık çalışanlarına karşı şiddet uygulamalarında cezalar ağırlaştırılmalı, sağlıkta şiddete sıfır tolerans ilkesi benimsenmelidir. Bununla birlikte tıpkı başarı ile yürütülen akılcı ilaç kullanımı kampanyası gibi hekimlerde defansif tıp uygulamalarının olumsuz etkileri konusunda farkındalığı arttırmak, hastalarda ise sağlık okuryazarlığını geliştirmeye yönelik çalışmalar yapılmalıdır.

Medyada sağlık ile ilgili sansasyonel haberler sıklıkla yer almakta, reyting uğruna hasta ve hasta yakınlarının ajite durumları ön plana çıkarılmakta ancak çoğu zaman bu haberler tek taraflı verilmektedir. Tedaviyi uygulayan hekim, sağlık kurumu veya konu hakkında uzman görüşü yansitılmamaktadır bunun sonucu olarak toplumda hekimlere olan güven zedelenmektedir. Hekimlerin yaptıkları veya yapmadıkları işlemler çok fazla sorgulanmaya başlanmakta bu da hekimler üzerinde baskı yaratarak onları defansif davranışlara itmektedir. Bu bakımdan medyada yer alacak sağlık haberleri konusunda hassas davranılması konu ile ilgili 
uzman görüşü ve tedaviyi uygulayanların görüşleri ile birlikte adli veya idari soruşturma açılmışsa sonucunun topluma aktarılması gerekmektedir.

Hekimler için uygulanan performans sisteminin sağlık hizmet sunumunun iyileştirilmesine çok büyük katkısı olmuştur ancak bugün gelinen noktada performans kaygısının gereksiz tıbbi işlemleri körüklediği göz ardı edilemez. Bu bakımdan performans sisteminin defansif tıp uygulamalarını azaltacak şekilde yeniden gözden geçirilmesi, işlem başı performans puanının minimuma indirilip, tedavi veya vaka başı performansın puanlamasının yaygınlaştırılması faydalı olacaktır.

Yapılan çalışmalarda pratisyen hekimlerin ve mesleki deneyimi az olan hekimlerin daha fazla defansif tıp davranışlarına yöneldiği görülmektedir. Yine tıp eğitiminde kalitenin de günden güne azaldığı, öğrencilerin yeterince hasta ve vaka görmeden mezun olduğu sık sık dile getirilmektedir. Bu bakımdan hekim adaylarına eğitim dönemi içinde tıp hukuku ile ilgili temel bilgilerin anlatılacağı bir ders konulması, göreve başladıktan sonra bu konularda eğitimler/seminerler verilmesi, kanıta dayalı tıbbi tedavi işlemlerini ayrıntılı olarak anlatan tıbbi bakım kılavuzları ve tanısal algoritmalara göre hekime yardımcı olacak karar destek sistemlerinin yaygınlaştırılması hekimlerin daha rahat hareket etmesine ve defansif davranışları azaltmalarına katkı sağlayacaktır.

Yapılan çalışmalar ${ }^{1}$ hekimlerin hasta veya hasta yakınları ile yaşadıkları sorunların temelinde zayıf iletişimin ve hastanın tıbbi işlemler konusunda tam olarak bilgilendirilmemesinin yattı̆̆ 1 vurgulanmaktadır. Bu bakımdan hekimlere eğitim sürecinde ve sonrasında hasta ile iletişim konusunda eğitim verilmelidir.

Günümüzde özellikle kamu sağlık tesislerinde hasta yoğunluğu çok fazla olmakta bunun negatif yansıması olarak da hekimler hastalara gerek fiziki muayene gerekse bilgilendirme için yeterince vakit ayıramamaktadır. Ancak herhangi bir bulguyu gözden kaçırmamak için gerekmediği halde tıbbi tetkikler istemektedir. Bu bakımdan hekime muayene için yeterli zamanı sağlayacak düzenlemelerin yapılması, randevu sisteminin istisnasız (acil durumlar hariç) uygulamaya konması defansif tıp uygulamaları azaltacaktır.

Defansif tıp uygulamaları kapsamında gereksiz yapılan tıbbi işlemlerin ekonomik boyutu göz önüne alındığında, hekimlerin yaptığı işlemlerin endikasyona uygunluk bağlamında belli aralıklarla denetlenmesi ve raporlanması bu tarz uygulamaların önüne geçecektir.

Literatürde hekimlerde defansif tıp uygulamalarının oranının yüksek olmasına rağmen defansif tıp kavramının içeriğinin tam olarak bilinmediği gözlemlenmiştir. Bu bakımdan

\footnotetext{
${ }^{1}$ Bu yönde çalışmalar için bkz. Yeşiltaş ve Erdem, 2018, Altındiş vd. 2009, Sun vd. 2019, Ali vd. 2016.
} 
hekimlerin defansif tıp kavramının içeriği, ekonomik ve etik boyutları konusunda bilgilendirmesi faydalı olacaktır.

$\mathrm{Bu}$ sistematik derleme çalışması kapsamında yapılan literatür taramasında özellikle Amerika ve Avrupa ülkelerinde defansif tıp uygulamalarının ekonomik boyutuyla ilgili çalışmaların yaygınlaşmaya başladığı ancak ülkemizde bu konuda çok sınırlı düzeyde birkaç çalışma dışında herhangi bir çalışma olmadığı gözlemlenmiştir. Bu bakımdan ülkemizde defansif tıp uygulamalarının ekonomik boyutuyla ilgili kapsamlı çalışmalara ihtiyaç duyulduğu söylenebilir.

\section{Kaynakça}

Ali, A. A. A., Hummeida, M. E., Elhassan, Y. A. M., Wisal, W. O., Ahmed, M. A. A. ve Adam, G. K. (2016). Concept of defensive medicine and litigation among Sudanese doctors working in obstetrics and gynecology. BMC Medical Ethics. doi:10.1186/s12910-0160095-3

Altındiş, S., Coşar, E., Atasoy, A. R., Akbaba, B., Şimşir, İ. ve Öz, S. (2019). Sağlık Uygulamalarında Defansif Tip. Ballkesir Medical Journal, 3(1), 12-19. doi:10.33716/bmedj.480177

Assing Hvidt, E., Lykkegaard, J., Pedersen, L. B., Pedersen, K. M., Munck, A. ve Andersen, M. K. (2017). How is defensive medicine understood and experienced in a primary care setting? A qualitative focus group study among Danish general practitioners. BMJ Open, 7(12), 1-8. doi:10.1136/bmjopen-2017-019851

Aydaş, S. (2014). Hekimlerde Malpraktis Kaynaklı Defansif Tıp Davranışları. (Yayınlanmamış Yüksek Lisans Tezi), Beykent Üni-versitesi Sosyal Bilimler Enstitüsü İşletme Yönetimi Anabilim Dalı, Hastane ve Sağlık Kurumları Yönetimi Bilim Dalı,. İstanbul.

Banaz, M. (2020). Hekimlerin defansif tip ve tibbi hata tutumlarinin incelenmesi. (Yayınlanmamış Yüksek Lisans Tezi), Hacetepe Üniversitesi Sosyal Bilimler Enstitüsü, Sağlık Yönetimi Programı, Ankara.

Başer, A., Kolcu, G., Çığırgil, Y., Kadınkız, B. ve Öngel, K. (2014). İzmir Karşıyaka İlçesinde Görev Y apan Aile Hekimlerinin Defansif Tıp Uygulamaları ile İlgili Görüşlerinin Değerlendirilmesi Evaluation of the Opinions of Family Doctors Working in Izmir Karsiyaka District on Defensive Medical Practices. Smyrna Tip Dergisi, 77, 16-24.

Baungaard, N., Skovvang, P., Assing Hvidt, E., Gerbild, H., Kirstine Andersen, M. ve Lykkegaard, J. (2020). How defensive medicine is defined and understood in European 
medical literature: Protocol for a systematic review. BMJ Open, 10(2), 1-4. doi:10.1136/bmjopen-2019-034300

Bergen, R. P. (1974). Medicolegal Rounds. JAMA: The Journal of the American Medical Association, 228(9), 1188. doi:10.1001/jama.1974.03230340076054

Bester, J. C. (2020). Defensive practice is indefensible: how defensive medicine runs counter to the ethical and professional obligations of clinicians. Medicine, Health Care and Philosophy, 23(3), 413-420. doi:10.1007/s11019-020-09950-7

Biçen, E. (2018). Tıpta Uzmanlık Öğrencilerinin Defansif Tıp Konusundaki Tutumlarının Araştırılması. Uzmanlık Tezi, Dokuz Eylül Üniversitesi, Tıp Fakültesi Adli Tıp Anabilim Dalı, İzmir.

Catino, M. (2011). Why do Doctors Practice Defensive Medicine? The Side-Effects of Medical Litigation. Safety Science Monitor, 15(1), 1-12.

Göçen, Ö., Y1lmaz, A., Aslanhan, H., Celepkolu, T., Tuncay, S. ve Dirican, E. (2018). Assistant Physicians Knowledge and Attitudes about Defensive Medical Practices, Work-Related Stress and Burnout Levels. Turkish Journal of Family Medicine and Primary Care, 12(2), 77-87. doi:10.21763/tjfmpc.432454

Hossein, D. ve Mina, M. (2018). Defensive Medicine : Ethical or Unethical ? A Case Study of Tehran University of Medical Sciences Hospitals. Journal of Public Health, 2(2). www.scientonline.org adresinden erişildi.

Kalkan, E., Özer, K., İzci, E. Ve Erdi, M. (2020). Beyin Ve Sinir Cerrahisi Uzmanlarının Tıbbi Uygulama Hatası Davaları Karşısında Defansif Tıp Uygulamalarının Belirlenmesine Yönelik Bir Araştırma. Journal of Healthcare Management and Leadership, (1), 54-69. doi:10.35345/johmal.726673

Kara, G. (2020). Sağlıkta Şiddet ve Defansif Tıp Uygulamaları Üzerine Nitel Bir Araştırma. (Yayınlanmamış Yüksek Lisans Tezi), Ondokuz Mayıs Üniversitesi Sağlık Bilimleri Enstitüsü, Sağlık Yönetimi Anabilim Dalı, Samsun.

Kara, K. S. (2020). Edirne 'deki Birinci Basamak Hekimlerinin Defansif Tip Uygulamalart Hakkında Bilgi ve Tutumları ve Bunun Klinik Pratiklerine Etkisi. (Yayınlanmamış Uzmanlık Tezi), Trakya Üniversitesi Tıp Fakültesi, Aile Hekimliği Anabilim Dalı,Edirne. Kumtepe, V., Meral, O. ve Gönüllü, H. (2020). Smyrna Tıp Dergisi Araştırma Makalesi İzmir v e Çevre İllerde ki Acil Tıp Asistanlarının Defansif ( Çekinik ) Tıp Uygulama Düzeylerinin İncelen mesi The Evaluation of Defensive ( Recessive ) Medicine Practices of Emergency Medical Assistants in Izmir and , 1-10.

Localio, A. R., Lawthers, A. G., Bengtson, J. M., Hebert, L. E., Weaver, S. L., Brennan, T. A. 
ve Landis, J. R. (1993). Relationship Between Malpractice Claims and Cesarean Delivery. JAMA: The Journal of the American Medical Association, 269(3), 366-373. doi:10.1001/jama.1993.03500030064034

Lyu, H., Xu, T., Brotman, D., Mayer-Blackwell, B., Cooper, M., Daniel, M., .. Makary, M. A. (2017). Overtreatment in the United States. PLoS ONE, 12(9), 1-11. doi:10.1371/journal.pone.0181970

Montanera, D. (2016). The importance of negative defensive medicine in the effects of malpractice reform. European Journal of Health Economics, 17(3), 355-369. doi:10.1007/s10198-015-0687-8

Morrison, M. C. . (1994). approached by. Journal of Royal Society of Medicine, 87(March), $127-128$.

Mutlu, H, H. ve Mutlu, H, H. (2019). Hasta Şikayetlerinin Aile Hekimlerinin Defansif Tip Davranışına Etkisi : İkincil Mağdurlar Aile Hekimleri mi ? Effects of Patient Complaints on Defensive Medicine Behavior of Family Physicians : Are Family Physicians the Second Victims ?, 0-3. doi:10.21673/anadoluklin.547289

Osti, M. ve Steyrer, J. (2017). A perspective on the health care expenditures for defensive medicine. European Journal of Health Economics. doi:10.1007/s10198-016-0848-4

Özata, M., Terlemez, A., Özer, K. ve Akkoca, Y. (2019). Defensive Dentistry: The Example of Konya. Turkiye Klinikleri Journal of Health Sciences, 4(2), 179-188. doi:10.5336/healthsci.2018-63278

Özer, K. ve Aslan, Ş. (2020). Araştırma Makalesi Defansif Tıp Uygulamalarının Belirlenmesi: Karma Yöntem Araştırması 1. Hacettepe Sağllk İdaresi Dergisi, 23(4), 639-664. https://orcid.org/0000-0003-2135-242X adresinden erişildi.

Pirol, M. (2018). Hekimlerin Karar Verme Algılarının Defansif Tıp Tutumları Üzerine Etkisinin Araştırılması. (Yayınlanmamış Yüksek Lisans Tezi), Selçuk Üniversitesi, Sağlık Bilimleri Enstitüsü, Sağlık Yönetimi Aanabilim Dalı, Konya.

Raposo, V. L. (2019). Defensive Medicine and the Imposition of a More Demanding Standard of Care. The Journal of legal medicine, 39(4), 401-416. doi:10.1080/01947648.2019.1677273

Reschovsky, J. D. ve Saiontz-Martinez, C. B. (2018). Malpractice Claim Fears and the Costs of Treating Medicare Patients: A New Approach to Estimating the Costs of Defensive Medicine. Health Services Research, 53(3), 1498-1516. doi:10.1111/1475-6773.12660

Rudey, E. L., Leal, M. do C. ve Rego, G. (2021). Defensive medicine and cesarean sections in Brazil. Medicine, 100(1), e24176. doi:10.1097/MD.0000000000024176 
Saruhan, N., Gojayeva, G. ve Altindiş, S. (2018). Diş Hekimlerinin Defansif Tip Uygulamalari Konusunda Tutumlarinin Değerlendirilmesi. J Biotechnol and Strategic Health Res, 2(3), 165-173. https://orcid.org/0000-0002-8941-9523 adresinden erişildi.

Studdert, D. M., Mello, M. M., Sage, W. M., DesRoches, C. M., Peugh, J., Zapert, K. ve Brennan, T. A. (2005). Defensive medicine among high-risk specialist physicians in a volatile malpractice environment. Journal of the American Medical Association, 293(21), 2609-2617. doi:10.1001/jama.293.21.2609

Summerton, N. (1995). Positive and negative factors in defensive medicine: a questionnaire study of general practitioners. BMJ, 310(6971), 27-29. doi:10.1136/bmj.310.6971.27

Sun, Z., Lin, S. X. ve Wang, S. (2019). An Economic Model of Optimal Penalty for Health Care Workplace Violence. Inquiry (United States). doi:10.1177/0046958019884190

Tancredi, L. R. ve Barondess, J. A. (1978). The Problem of Defensive Medicine, 879-882. doi:10.1126/science.644329

Tebano, G., Dyar, O. J., Beovic, B., Béraud, G., Thilly, N. ve Pulcini, C. (2018). Defensive medicine among antibiotic stewards: The international ESCMID AntibioLegalMap survey. Journal of Antimicrobial Chemotherapy, 73(7), 1989-1996. doi:10.1093/jac/dky098

Toraman, A. ve Çarıkçı, İ. H. (2019). Defansif Tibbi Nedenlerinin Hekim Gözüyle Değerlendirilmesi. Süleyman Demirel Üniversitesi Vizyoner Dergisi, (February 2019), 40-51. doi:10.21076/vizyoner.438697

U.S. Congress, O. of T. A. (1994). Defensive Medicine and Medical Malpractice. Hospital technology series, 13(15).

Ünal, Ö. (2020). Defansif Tıp Uygulamaları, Öncülleri ve Sonuçları. (Yayınlanmamış Doktora Tezi). Sakarya Üniversitesi, İşletme Enstitüsü, Sakarya.

Virapongse, A., Bates, D. W., Shi, P., Jenter, C. A., Volk, L. A., Kleinman, K., ... Simon, S. R. (2008). Electronic health records and malpractice claims in office practice. Archives of Internal Medicine, 168(21), 2362-2367. doi:10.1001/archinte.168.21.2362

Yahata, S. (2011). Center for Applied Ethics and Philosophy. A Study of Defensive Medicine in Japan, 175-186.

Yan, S. C., Hulsbergen, A. F. C., Muskens, I. S., van Dam, M., Gormley, W. B., Broekman, M. L. D. ve Smith, T. R. (2017). Defensive medicine among neurosurgeons in the Netherlands: a national survey. Acta Neurochirurgica, 159(12), 2341-2350. doi:10.1007/s00701-017-3323-9

Yeşiltaş, A. ve Erdem, R. (2018). Şiddet Ve Defansif Tıp Uygulamaları Üzerine Nitel Bir 
Çalışma. the Journal of Academic Social Sciences, 74(74), 486-500. doi:10.16992/ASOS.13871

Yılmaz, K., Polat, O. ve Begüm, K. (2014). Defansif Tıp Uygulamalarının Hukuksal Açıdan İncelenmesi. Türkiye Adalet Akademisi Dergisi, 5.

Yorulmaz, M. ve Sabırlı, H. (2019). Sağlık Hizmetleri Arzında Defansif Tıp Ve Hekimlerin Karar Verme Alg1s1. Business \& Management Studies: An International Journal, 7(2), 579-590. doi:10.15295/bmij.v7i2.1121

Zarei, E., Ashtar-Nakhaei, F., Daneshkohan, A. ve Zali, A. (2019). The first survey on defensive medicine among Iranian surgeons: prevalence and its related factors, 1-16. doi:10.21203/rs.2.10972/v1

Zhu, L., Li, L. ve Lang, J. (2018). The attitudes towards defensive medicine among physicians of obstetrics and gynaecology in China: A questionnaire survey in a national congress. BMJ Open, 8(2), 1-7. doi:10.1136/bmjopen-2017-019752 